\title{
A comparative assessment: methods of growth of potato minitubers in summer greenhouses and in field under a covering material in the climate conditions of the Middle Volga region
}

\author{
Vladimir Molyanov ${ }^{1}$, Oleg Vinogradov ${ }^{2, *}$, Natalya Ivanayskaya $^{3}$, Natalya Kuvshinova ${ }^{2}$, \\ Ilya Molianov ${ }^{1,4}$ \\ ${ }^{1}$ Molyanov Agro Group LLC, 446442, Kinel, Samara Region, Russia \\ ${ }^{2}$ Union of Potato Growers of Samara Region, 136-92, Novo-Vokzalnaya str., 443111, Samara, Russia \\ ${ }^{3}$ Agrostar LLC, Pokhvistnevsky District, 446494, Samara Region, Russia \\ ${ }^{4}$ Lorch Potato Research Institute, 23, Lorkh str., 140051, Kraskovo, Lyubertsy district, Moscow \\ region, Russia
}

\begin{abstract}
The article presents the results of the comparison of two methods for potato minitubers cultivation, namely: in summer-type greenhouses and in field under a covering material in the climate conditions of the Middle Volga, Russia. This assessment was undertaken in the breeding and seed center of Agrostar LLC. The objective of the work is to assess the economic efficiency of both technologies for potato minitubers cultivation and justify the possibility of using the best of them for implementation in the original seed production. The micro-plants for the study were obtained from the biotechnological laboratories of the Samara Scientific Research Institute of Agricultural Sciences and the seedgrowing farm Tsirulev E.P., Samara region. The results obtained indicate that the most effective method of growth potato minitubers is in field under a covering material. This work was carried out as part of a comprehensive scientific and technical project "Development of breeding and seed production of potatoes in the Samara region". Russian and Western European cultivars were used in the study.
\end{abstract}

\section{Introduction}

It is well known that seed production is an important element in the organizational structure of potato production. This is a branch of plant growing involved in the reproduction of seeds, improving and keeping their productivity and sowing varietal traits. Final yields and gross harvests of crops are increased up to $25 \%$ due to the introduction of high-quality seeds of newly registered and promising varieties into the crop rotation $[1,2]$.

In the practice of seed farming, various methods are used to produce minitubers: hydroand aeroponic propagators, greenhouses, hotbeds, tunnel greenhouses with supporting structures to protect micro-plants from damage [3-5].

*Corresponding author : unionkart@gmail.com 
These methods of production of minitubers require a significant one-time (investment) cost for creating a protected environment that provides optimal conditions for the life and development of plants. These include the construction of bulky, expensive load-bearing and enclosing structures and artificial systems that require large operating costs [6]. Usually, plants are placed in pots and plastic boxes on shelves or on a flat surface (for example, in tunnel greenhouses). The plant placement in such protected areas are determined by the space-planning and structural solution of the room [7,8]. This limits the scope and increases the cost of production per unit area. In turn this does not favor the production of many minitubers and does not allow to make in a short time a reliable assessment of the economically significant features of new varieties of potatoes created in the process of breeding. An additional problem that arises when using such methods to produce minitubers is the inability of organisms grown in an artificial environment to adapt to the conditions of the natural habitat, as well as their low resistance to external environmental factors [9-11]. A weaker immune system formed in an artificial environment affects the health of the first field generation and subsequent generations, the production of which is determined by the Russian Standard GOST 33996-2016 for original, elite and reproductive seed growing.

In modern conditions, an important promising direction of the search is to identify effective ways to optimize the seed growing process, especially in the direction of reducing material, labor, energy costs and decreasing the cost of production of elite seed material. Therefore, research into alternative technologies is required [12-14]. The objective of the work is to evaluate the economic efficiency of two technologies for growing potato minitubers (in a greenhouse and in a field under a covering material) and justify the applicability of the best of these methods for the implementation in original seed growing.

\section{Material and methods}

For the purposes of the study conducted as part of a comprehensive scientific and technical project "Development of selection and seed production of potatoes in the Samara region", micro-plants obtained in vitro were planted [15]. The study was carried out in greenhouses and field conditions, in the breeding and seed center of Agrostar LLC, Pokhvistnevsky district, Samara region (Russia) in 2019. The predecessors in the field were annual grasses black steam.

The climate in the Samara region is temperate continental, where more than half the time of the year the anticyclone type of weather prevails. The average monthly temperature in July is plus $21^{\circ} \mathrm{C}$, in January - minus $14^{\circ} \mathrm{C}$. Relative humidity is about $70 \%$, the average precipitation is $554 \mathrm{~mm}$ (1969-2019), $534 \mathrm{~mm}$ (2019). The height of the snow cover ranges from 35 to $75 \mathrm{~cm}$. The absolute maximum air temperature in Samara is plus $40^{\circ} \mathrm{C}$, and the absolute minimum is minus $43^{\circ} \mathrm{C}$. During the growing season of 2019 , weather conditions in the Samara region were within the average annual indicators.

The soil of the experimental plot is loamy "chernozem" (black soil) containing of $\mathrm{N}_{\text {tot. }}$ $98 \mathrm{mg} / \mathrm{kg}, \mathrm{P}_{2} \mathrm{O}_{5}-225 \mathrm{mg} / \mathrm{kg}, \mathrm{K}_{2} \mathrm{O}-190 \mathrm{mg} / \mathrm{kg}$. Potato cultivation agricultural technology used is traditional with chemical treatments against diseases and pests. Irrigation used of - drip type. Observations and control were carried out according to generally accepted methods in Russia.

Planting of micro-plants was carried out in three greenhouses and in a field under covering material. The plot in the field for planting potato micro-plants was isolated from possible sources of infection.

The site chosen was even, rectangular in shape as the configuration is important: practice shows that in narrow areas, infection, transmitted by winged aphids, spreads to a greater extent. When preparing for the studies, the following elements were considered: the 
soil features, methods of cultivation, the ratio of different nutrients, the requirements for the preparation of planting material, the timing of planting and harvesting.

By May 10, 2019, the employees of the breeding and seed center of Agrostar LLC prepared the greenhouses for planting. This included leveling of the soil surface, arranging technological paths, and sheltering of the soil with a black film. When preparing the soil, sand with peat and a special mixture (lowland, peat and organic fertilizer "Biocompost" with the addition of baking powder and limestone materials) were used and a complex mineral fertilizer was introduced. In early May, from the biological laboratories of the Samara Scientific Research Institute of Agricultural Sciences and seed-growing farm Tsirulev E.P. planting material (micro-plants) was obtained. These are three promising Russian cultivars of Lorch Potato Research Institute (Moscow) selection and five cultivars of foreign selection (Table 1).

Table 1. Characteristics of the potato cultivars.

\begin{tabular}{|c|c|c|c|c|c|c|}
\hline Name term & Ripening & Peal & Pulp & \multicolumn{2}{|c|}{ Productivity, t/ha } & $\begin{array}{c}\text { Marketability, } \\
\text { starch content, } \%\end{array}$ \\
\cline { 5 - 6 } $\begin{array}{c}\text { Gulliver } \\
\text { (RF) }\end{array}$ & early ripe & $\begin{array}{c}\text { light } \\
\text { beige }\end{array}$ & cream & $16.3-28.3$ & 37.1 & $\begin{array}{c}84-98, \\
14.1-15.4\end{array}$ \\
\hline Grand (RF) & $\begin{array}{c}\text { mid- } \\
\text { ripening }\end{array}$ & $\begin{array}{c}\text { partially } \\
\text { red }\end{array}$ & $\begin{array}{c}\text { light } \\
\text { yellow }\end{array}$ & $11.4-38.7$ & 50.6 & $\begin{array}{c}75-96, \\
13.4-18.0\end{array}$ \\
\hline Violet (RF) & mid-late & blue & blue & $6.0-20.9$ & 22.1 & $\begin{array}{c}66-77 \\
10.5-14.4\end{array}$ \\
\hline $\begin{array}{c}\text { Capri } \\
\text { (Germany) }\end{array}$ & very early & yellow & yellow & $18.4-23.6$ & 25.7 & $\begin{array}{c}82-93 \\
14.2-16.2\end{array}$ \\
\hline $\begin{array}{c}\text { Riviera } \\
\text { (NL) }\end{array}$ & early ripe & $\begin{array}{c}\text { light } \\
\text { beige }\end{array}$ & cream & $18.9-36.6$ & 46.5 & $\begin{array}{c}80-96 \\
11.5-15.9\end{array}$ \\
\hline $\begin{array}{c}\text { Secura } \\
\text { (Germany) }\end{array}$ & mid early & yellow & yellow & $19.5-32.3$ & 36.5 & $\begin{array}{c}79-96 \\
13.0-18.2\end{array}$ \\
\hline $\begin{array}{c}\text { Crone } \\
\text { (Germany) }\end{array}$ & mid early & yellow & yellow & 43 & 65.0 & $\begin{array}{c}\text { high } \\
9.0-12.0\end{array}$ \\
\hline $\begin{array}{c}\text { Sanjava } \\
\text { (Germany) }\end{array}$ & mid early & yellow & yellow & $37.0-40.0$ & 60.0 & $\begin{array}{c}\text { high } \\
12.0-13.0\end{array}$ \\
\hline
\end{tabular}

On May 11-12, micro-plants grown by the roll method in the greenhouses were planted (Fig. 1, Fig. 2). Micro-plants were planted manually - 30 plants per square meter [16]. When planting, the chemical compound BisolbiSan was used. This is a contact fungicide (bactericide) and seed dressing to combat several diseases. It regulates growth processes through the synthesis of physiologically active compounds and increases the availability of nutrients from the soil and fertilizers through the synthesis of organic acids and enzymes. This drug activates the immunity of plants to bacterial and fungal diseases. In this case, plants take root better. Drip irrigation was installed. In greenhouses, potato micro-plants can suffer greatly from exposure to high daytime temperatures and direct sunlight. A polymer shading net was stretched over with a 55\% solar dimming index to prevent damage. In cloudy weather, the net was pushed to the side. At the same time a field was prepared, cultivation was carried out, complex mineral fertilizers were introduced (dose and composition, as in greenhouses), ridges were cut, drip tapes for irrigation were laid. Also, on May 11, micro-plants were planted 


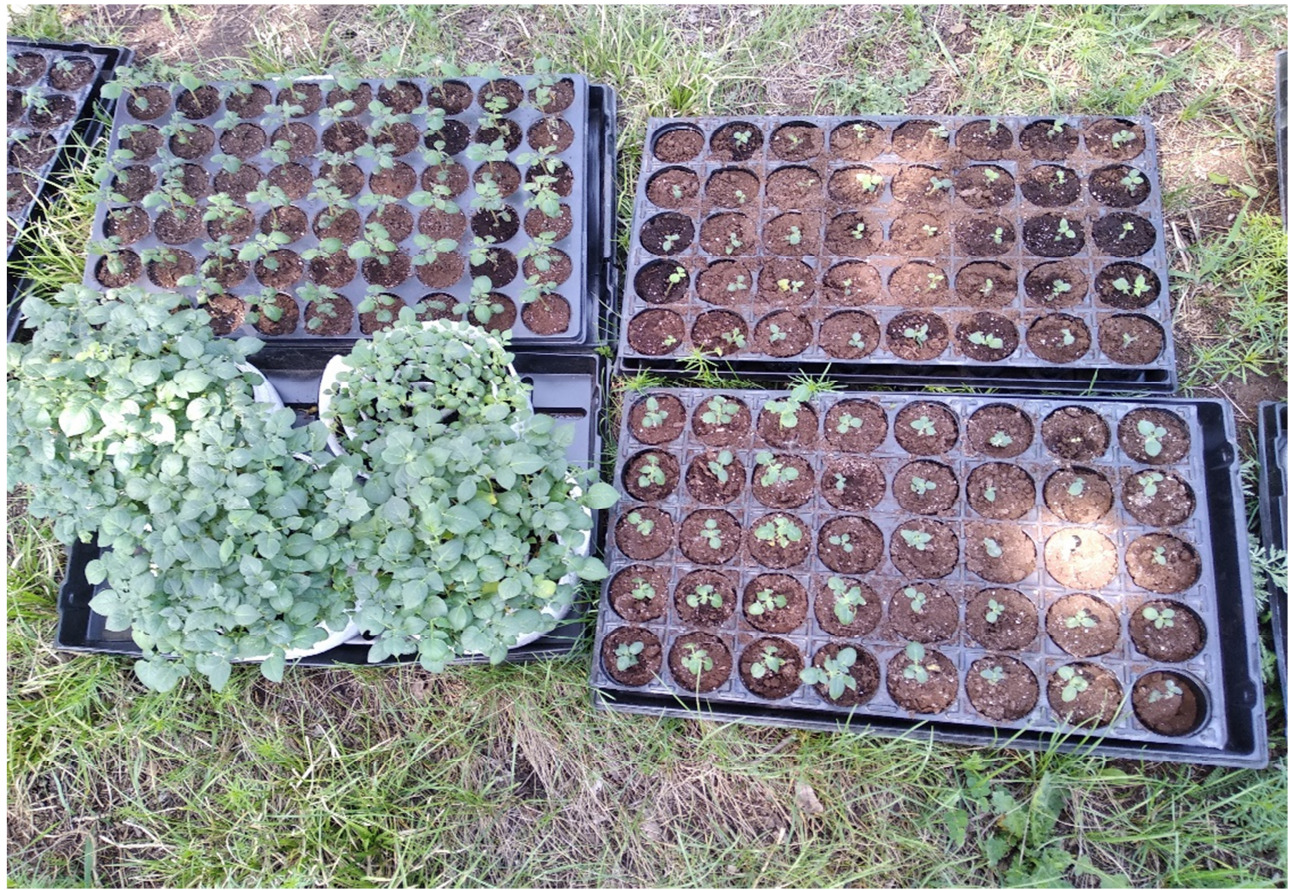

Fig. 1. Planting material

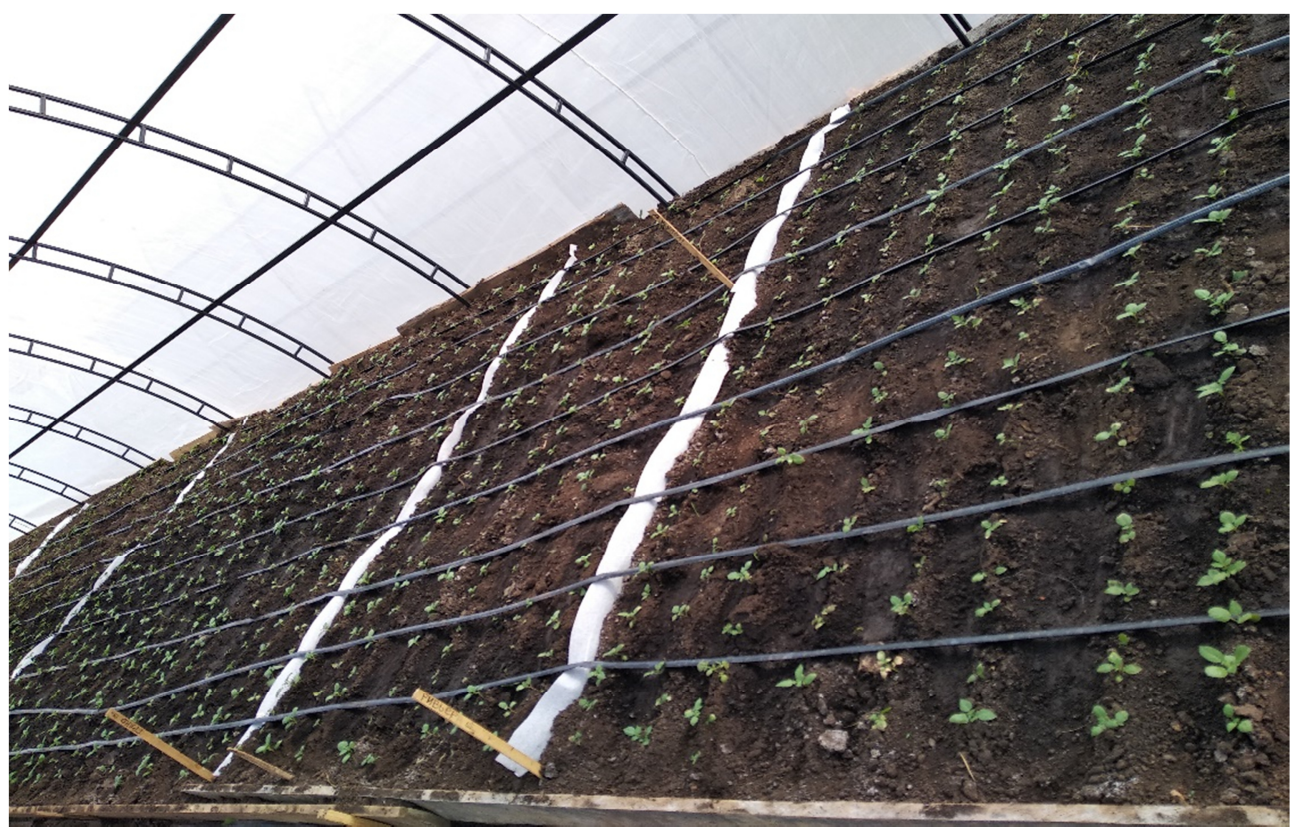

Fig. 2. planted seedlings in the greenhouse.

in the field (Fig. 3) with simultaneous treatment with BisolbiSan and subsequent covering with covering material (Fig. 4). A dense and light anti-insect network covering of high strength made of monofilament polyethylene with hole sizes of $0.27 \times 0.83 \mathrm{~mm}$ was 
used. The covering has a translucent color, providing maximum illumination to potato micro-plants and protection against different types of insects.

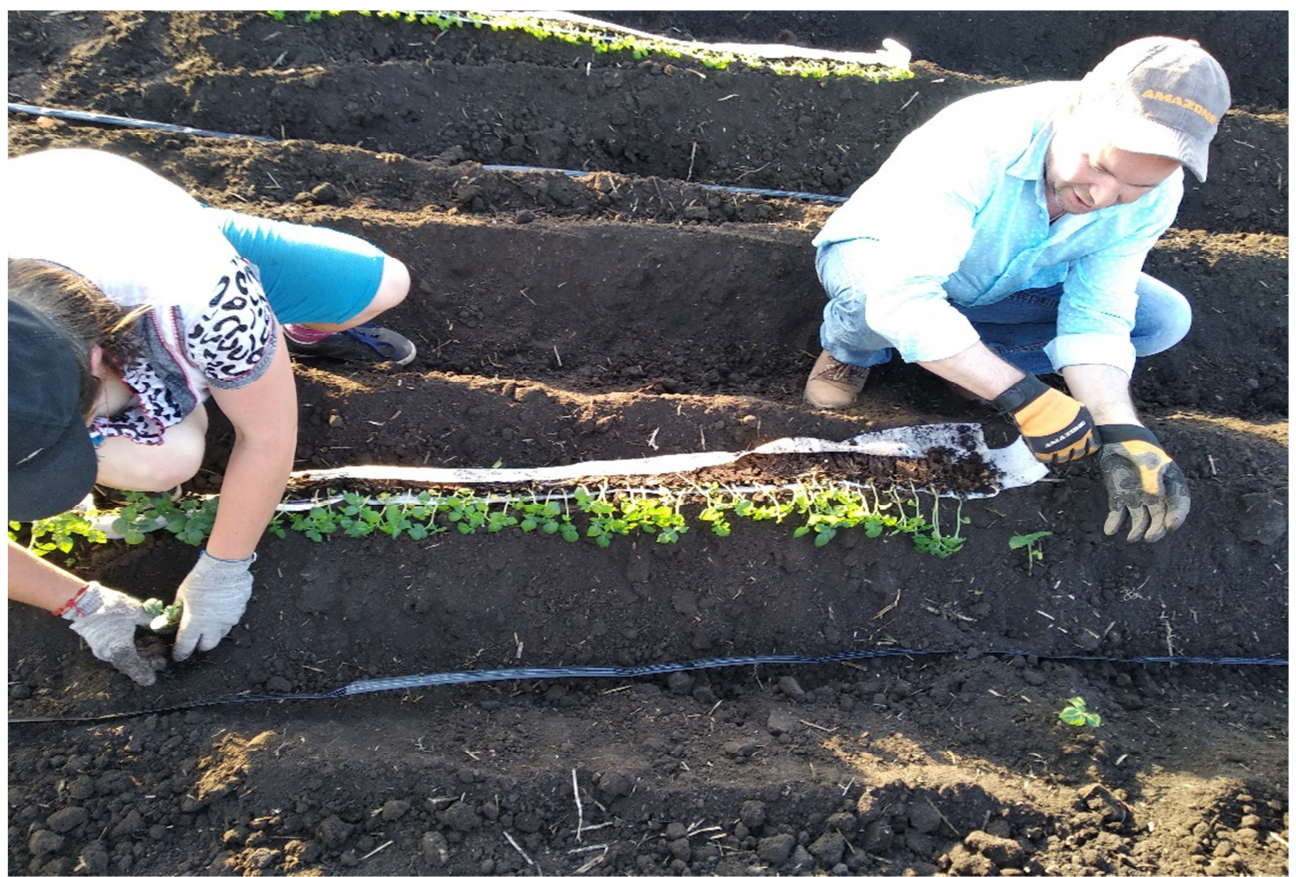

Fig. 3. Planting seedlings in the field.

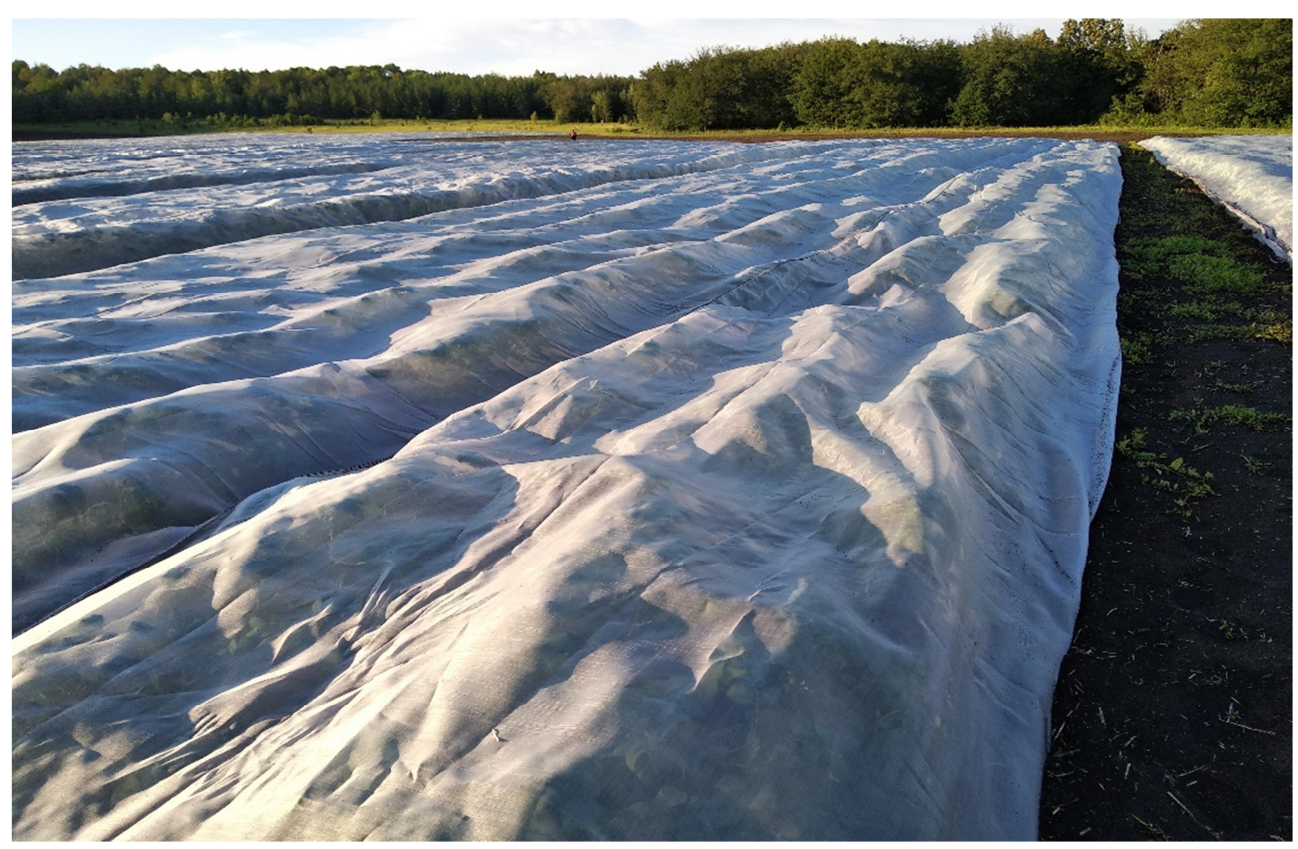

Fig. 4. Micro-plants in the field under covering material.

Four potato cultivars were planted in the field: domestic hybrids (Grand, Gulliver, Violet) and the foreign Riviera hybrid (NL). During the growing season, regular watering 
and weekly treatment of plants in all three greenhouses with fungicides and insecticides were carried out as well as weeding, cultivation and hilling of plants. Throughout the summer, non-typical and diseased plants were regularly screened in greenhouses. The struggle with aphids - virus carriers (indicator "flags" and yellow pan traps "Moericke traps") were set. Leaves feeding was carried out.

The tops were desiccated when the physiological maturity of the tubers was reached. In the field, all treatments with herbicides, fungicides and insecticides were carried out through the covering material with an Amazone UR 3000 sprayer at a pressure of 3.5 atmospheres. Twice during the growing season, the network covering was briefly opened for cultivation, hilling and visual inspection of plants. Leaves feeding during the growing season was not performed. Early harvesting of tubers was carried out prior to the identification of late blight. The use of contact desiccant REGLON SUPER, BP accelerated the process of drying the tops. On August 15, minitubers were collected from greenhouses No. 1 and No.2, in greenhouse No. 3 collection of minitubers concluded on September 20. After harvesting, the tubers were dried, greened, and put in boxes with the name of the cultivar on the labels. After 1.5-2 weeks, the boxes were placed in a refrigerator $\left(+3-+4^{0}\right.$ C) for storage.

\section{Results}

The results of the experimental comparison of both technologies for producing minitubers is presented in Table 2 and Table 3.

Table 2. The number of plants and tubers of micro-plants in greenhouses.

\begin{tabular}{|c|c|c|c|c|}
\hline \multirow{2}{*}{ Cultivar } & \multicolumn{2}{|c|}{ Micro-plants, pes. } & Minitubers & Breeding rate, \\
\cline { 2 - 3 } & Planted & $\begin{array}{c}\text { Before } \\
\text { harvesting } \\
\text { pcs. }\end{array}$ & 1336 & 3.4 \\
\hline Capri & 491 & 216 & 3914 & 3.5 \\
\hline Secura & 1095 & 825 & 5526 & 3.4 \\
\hline Gulliver & 1586 & 1316 & 4286 & 2.9 \\
\hline Riviera & 1175 & 905 & 5125 & 4.3 \\
\hline Grand & 1168 & 898 & 1862 & 3.4 \\
\hline Sanjava & 650 & 380 & 2095 & 3.2 \\
\hline Crone & 629 & 359 & 1476 & 4.1 \\
\hline Violet & 357 & 357 & 25620 & 3.5 \\
\hline Total & 7151 & 5256 & \multicolumn{2}{c}{} \\
\hline
\end{tabular}

In the 4th quarter of 2019 , the analysis of the efficiency of the production of minitubers under various conditions of closed ground (greenhouse) and open ground (field) was completed, which confirmed the increased performance of an alternative production method in the open ground.

Table 3. The results of growing minitubers in greenhouses set aside to determine the effectiveness of the method of production of minitubers.

\begin{tabular}{|c|c|c|c|c|}
\hline \multirow{2}{*}{ Cultivar } & \multicolumn{2}{|c|}{ Micro-plants, pes. } & \multirow{2}{*}{$\begin{array}{c}\text { Minitubers } \\
\text { harvested, pes. }\end{array}$} & $\begin{array}{c}\text { Breeding rate, } \\
\mathbf{B r}\end{array}$ \\
\cline { 2 - 3 } & planted & 357 harvesting & 1476 & 4.1 \\
\hline Violet & 357 & 898 & 5125 & 4.3 \\
\hline Grand & 1168 & 1316 & 5526 & 3.4 \\
\hline Gulliver & 1586 & 905 & 4286 & 2.9 \\
\hline Riviera & 1175 & 3476 & 16413 & 3.8 \\
\hline Total & 4286 & & & \\
\hline
\end{tabular}


Table 4. The results of growing minitubers in the field.

\begin{tabular}{|c|c|c|c|c|}
\hline \multirow{2}{*}{ Cultivar } & Mlanted & $\begin{array}{c}\text { Micro-plants, pes. } \\
\text { before } \\
\text { harvesting }\end{array}$ & $\begin{array}{c}\text { Minitubers } \\
\text { harvested, } \\
\text { pcs. }\end{array}$ & $\begin{array}{c}\text { Breeding rate } \\
\text { (Br) }\end{array}$ \\
\hline Violet & 339 & 339 & 1359 & 4.0 \\
\hline Grand & 428 & 428 & 2159 & 5.04 \\
\hline Gulliver & 406 & 406 & 1660 & 4.08 \\
\hline Riviera & 232 & 232 & 724 & 3.12 \\
\hline Total & 1405 & 1405 & 5902 & 4.2 \\
\hline
\end{tabular}

As the study has shown, the Breeding rate $(\mathrm{Br})$ value for almost all cultivars in the field was higher than in greenhouses. An exception occurred only in the Violet cultivar, in which a decrease in $\mathrm{Br}$ by $3.29 \%$ was observed. It should be noted that the validity of the indicator $\mathrm{Br}$ is observed even though in the greenhouses the plants received additional leaves feeding with liquid mineral fertilizers. In the greenhouses, some plants were discarded as a result of phyto cleaning, $18.9 \%$ of non-typical, diseased plants from the originally planted microplants were removed. Representative samples of minitubers were checked to find the presence of viral infections. According to the conclusion of an independent potato quality control laboratory, tubers were not affected by viruses in either the greenhouses or in the field. As a result of the study, the high efficiency of the method for growing minitubers from micro-plants under a covering material in the field was confirmed as compared to growth in greenhouses. The Breeding rate in the field is $11 \%$ higher than that for the greenhouses. Costs per unit are on average lower by $49.4 \%$ in the field compared to greenhouses (Table 5).

Table 5. Actual costs and costs per 1 micro-plant (MP). Evaluation of the economic efficiency of two technologies for minitubers growing.

\begin{tabular}{|l|c|c|c|c|}
\hline \multirow{2}{*}{ Naming of costs } & \multicolumn{4}{c|}{$\begin{array}{c}\text { The costs of the entire complex of works for } \\
\text { greenhouse and field conditions, rubles (Exchange } \\
\text { rate: 1 ruble = 0.0159 USD) }\end{array}$} \\
\cline { 2 - 5 } & \multicolumn{2}{|c|}{ Actual costs } & \multicolumn{2}{c|}{ Costs per 1 MP } \\
\cline { 2 - 5 } & Greenhouses & Field & Greenhouses & Field \\
\hline Covering network & 3762.2 & 6875 & 0.9 & 4.9 \\
\hline Tara (boxes, buckets, etc.) & 4696 & 746 & 1.1 & 0.5 \\
\hline Soil, peat & 19263.3 & 0 & 4.5 & 0 \\
\hline Consumables and building materials & 33066.5 & 0 & 7.7 & 0 \\
\hline Fertilizers and plant protection & 1044.7 & 5574 & 0.2 & 3.97 \\
\hline Micro-plants & 92645.1 & 30370.1 & 21.6 & 21.6 \\
\hline Greenhouseas (amortization incl.) & 97113.8 & 0 & 22.7 & 0 \\
\hline Emitter drip tape & 866.1 & 2398 & 0,2 & 1.7 \\
\hline Diesel fuel for irrigation pump & \multicolumn{5}{|l|}{} & 0 & 0.5 \\
\hline Remuneration of labour & 65594.4 & 6099.7 & 15.3 & 4.3 \\
\hline Total & 318052.1 & 52759.8 & 74.2 & 37.6 \\
\hline Calculation results & 4286 & 1405 & & \\
\hline Number of micro-plants, pcs. & \multicolumn{5}{|l}{} \\
\hline
\end{tabular}




\begin{tabular}{|l|c|c|c|c|}
\hline Number of minitubers, pcs. & 16413 & 5902 & & \\
\hline $\begin{array}{l}\text { The number of minitubers per 1 } \\
\text { micro-plant, pcs. }\end{array}$ & & & 3.8 & 4.2 \\
\hline Cost of 1 minituber, rubles & & & 40.2 & 22.2 \\
\hline $\begin{array}{l}\text { The increase in the number of } \\
\text { minitubers, \% }\end{array}$ & & & 100 & 110.6 \\
\hline Cost reduction,\% & & & & -49.4 \\
\hline
\end{tabular}

\section{Conclusions}

Based on an experimental verification of the technology for the production of potato minitubers under covering material, it is possible to get significant increase of the productivity of the process and reduce operating costs, as well as to create a protected zone that ensures the development of plants in favorable environmental conditions and ensure the production of healthy progeny with increased immunity. The technology used allows us to organize the industrial production of potato minitubers (1-2 vegetations per year) in large volumes (millions of pieces per year). These volumes classify the production as industrial where each plant grows at least four pieces of full potato minitubers with an average weight of 30 grams each from one vegetation.

\section{Acknowledgements}

Authors acknowledge the financial assistance received from the Ministry of Agriculture of Russian Federation under the comprehensive scientific and technical project "Development of breeding and seed production of potatoes in the Samara region."

\section{References}

1. B.V. Anisimov, S.N. Zebrin, S.I. Loginov, A.A. Kuzmichev, Potatoes and vegetables 7, 20-21 (2016)

2. E.A. Simakov, B.V. Anisimov, S.V. Zhevora, A.V. Mityushkin, A.A. Zhuravlev, Al-r V. Mityushkin, A.S. Gayzatulin, Potatoes and vegetables 2, 35 (2020)

3. I. Dimante, Z. Gaile, Research for Rural Development 1, 76 (2014)

4. K. Bag, A.K. Srivastava, S.K. Yadav, M.S. Gurjar, L.C. Diengdoh, R. Rai, S. Sukhwinder, Indian Journal of Agricultural Sciences 85(10), 1360-4 (2015)

5. M. Särekanno, J. Kadaja, K. Kotkas, V. Rosenberg, V. Eremeev, Soil \& Plant Science 62(2), 114-124 (2012) doi: 10.1080/09064710.2011.581680

6. M. Zangeneh, M. Omid, A. Akram, Spanish Journal of Agricultural Research 9(3), 661-671 (2011)

7. R. Tierno, A. Carrasco, E. Ritter, J.I. Ruiz de Galarreta, American Journal of Potato 91(4), 346-353 (2014) DOI: 10.1007/s12230-013-9354-8

8. H. Gebru, A. Mohammed, N. Dechassa, D. Belew, Agriculture \& Food Security 6, 31 (2017)

9. A.K. Sharma, K.K. Pandey, Potato Journal 40(2), 95-103 (2013)

10. T. Buckseth, A.K. Sharma, K.K. Pandey, B.P. Singh, R. Muthura, Scentia Horticulturae 204, 79-87 (2016) 
11. P. Lindhout, D. Meijer, T. Schotte, R.C.B. Hutten, R.G.F. Visser, H.J. Van Eck, Pot. Res. 54, 301-312 (2011)

12. J. Muthoni, J. Kabira, H. Shimelis, R. Melis, Australian Journal of Crop Science 8(8), 1147-1151 (2014)

13. H.R. Roosta, M. Rashidi, H.R. Karimi, H. Alaei, M. Tadayyonnejhad, J. Sci. \& Technol. Greenhouse Culture 4(14), 80 (2013)

14. N. Hennouni, F. Taibi, K. Madi, T. Kestali, Advances in Environmental Biology 10(7), 90-98 (2016)

15. V.D. Molyanov, O.G. Vinogradov, A.V. Milekhin, A.V. Vasin, Rosinformagrotech, Information Bulletin of the Ministry of Agriculture of Russia 5, 20-22 (2019)

16. A.J. H. van der Veeken, W. J. M. Lommen, Potato Research 52(2),105-119 (2009)

17. J.M. Crosslin, L. Hamlin, Plant Disease 94(12), 1507-1507 (2010) DOI: 10.1094/PDIS-07-10-0542 